\title{
1. Introduction: aging and working in the New Economy
}

\section{Julie Ann McMullin and Victor W. Marshall}

This book is about aging and working in the New Economy. It is about how individuals manage their paid work within firms that are struggling to survive and compete in global economies. It is also about the tensions that arise as workers and owners struggle for personal and firm survival, two processes that are often contradictory and result in paradoxes that occasionally produce conflict. For centuries, of course, tension, contradiction, paradox, and conflict have been used to describe the employment relations that exist between employers and employees. Yet, as this book will show, the specific character of employment relations and the tension, contradiction, paradox, and conflict that ensue, take on a somewhat different character in the small, New Economy firms in this study.

Throughout the 1990s, the New Economy concept came to refer to the idea that old ways of doing business were waning, largely due to advances in information technology, the innovative implementation of these technologies in the workplace, and the commodification of knowledge (Castells, 1996; Ranson, 2003). Although there have been debates about how new the New Economy really is, the evolution of employment relations over the last several decades and the idea that 'business is not being conducted as usual' have policymakers, think tanks, and academics taking notice. Indeed, according to Chris Benner 'it is not at all an exaggeration to say that we are in the midst of an information revolution as significant for changing economic and social structures in the twenty-first century as the first and second industrial revolutions were for the nineteenth and twentieth centuries' (Benner, 2002: 1-2). Although it is difficult, and perhaps premature, to say for certain whether the changes in the use of information technology could be classified as a revolution of the same magnitude and scope as the first and second industrial revolutions, one need only consider the vast changes in manufacturing processes and the omnipresence of email and text messaging at work and at home to recognize that profound change is underway.

The transformation of employment relations in the New Economy has coincided with workforce aging. Over the next few decades, population 
and workforce aging in industrialized nations will occur at unprecedented rates, reducing the indigenous supply of younger workers entering the labor force. Potential labor shortages in certain knowledge-based industrial sectors, along with concerns about financial support of retirees, and the need for companies in fast-paced industries to respond rapidly to market demands, have prompted commentators to argue that a critical issue facing industrialized countries is the retention and retraining of workers throughout the life course. This will require encouraging employers and governments to develop workplace and social policies that consider the changing needs and capacities of workers across the life course so that they can remain productive over a longer term.

Understanding the complexities associated with aging and working in new economies requires a multi-level analysis that takes into account processes of globalization as they are realized in local contexts, the place of firms within these processes, and the situation of individuals within these firms. The 'life course perspective' is well suited to such an analysis and guides our work by providing a conceptual framework for analysing the complex relationships between individual lives and social change. New economic realities mean that individuals face rapidly changing labor markets and these realities have ramifications that extend across the life course. Yet, research has not explicitly considered what it means to age and work in a New Economy industry from a life course perspective. Hence, the primary objective of this book is to contribute to our understanding of how careers take shape as workers age within the context of a changing labor market. In this chapter, we begin with a discussion of our study design and then briefly outline some of the key concepts of the life course perspective as they relate to aging and working in the New Economy. As we discuss these life course concepts we also introduce and provide brief overviews of the chapters in this book.

\section{WANE: THE WORKFORCE AGING IN THE NEW ECONOMY STUDY}

The chapters in this book draw on data from the project, 'Workforce Aging in the New Economy Project: A Comparative Study of Information Technology Firms,' an international study that was funded in 2002 by the Social Sciences and Humanities Research Council of Canada (for more details about the project see www.wane.ca). The broad objective of WANE was to study the intersection of workforce aging and the restructuring of work within information technology (IT), an industrial sector that may be considered a benchmark case of a New Economy. Because we were interested in highly skilled, knowledge work that is characteristic 
of New Economy employment, our primary focus in this study was with a subsector of IT firms, those that are classified as software and computer systems design and services under the North American Industry Classification 54151 (Duerden Comeau, 2004: 1).

The WANE project examined the nature of work within the IT industry and how employment relations and human resource practices shape and are shaped by the life course transitions of workers. To examine these issues, a team of researchers conducted case study research in small and mid-sized information technology sector firms located in four countries, Australia, Canada, England, and the United States.

To address our study objectives, we conducted in-depth assessments of IT employment from the perspective of both employers and employees. We used a case study research design which allowed us to consider multiple points of view that, when taken together, provide us with a more complete understanding of the relationships among members in a given organization (see Marshall, 1999; Ragin, 2000; see also Chapter 3). In the WANE study, a case is broadly defined as an IT firm and several criteria were established for firms to be eligible for participation in the study. Firms had to be in operation at least one year and have four or more staff. The conditions of participation could not compromise data collection. Thus, firms were required to support employee involvement in the study, provide access to HR documents, and in most cases, allow researchers to observe on site for a predetermined amount of time. A focus on smaller businesses was salient as very little research on IT work has considered small to medium-sized enterprises (SMEs), which are in fact quite prevalent in all of our study countries. For example, in 2001, 96 percent of IT firms in Canada and 93 percent of computer services businesses in the United Kingdom (UK) employed less than 10 people (Bjornsson, 2001; Da Pont, 2003). Similarly, in Australia, 88 percent of IT firms employ 0-4 workers and 29 percent of IT workers were employed in small firms in 2001 (Brooke et al., 2004). Data from the US show that 85.3 percent of IT firms employed fewer than 10 workers in 2006 (United States Census Bureau, 2006).

Within each country, IT firms were further targeted on criteria suited to the particular region and industry context. Geographical location was a primary and effective means of seeking participants, for convenience and cost effectiveness, and also because of the proximity, and in some cases, association of researcher post-secondary institutions with sector 'hot beds' - regions in which there is a relatively high concentration of IT activity. Table 1.1 outlines the cities and regions from which the case studies were selected in each country. In some regional contexts, particularly Australia and England, case firms were also monitored in order to maximize heterogeneity beyond the baseline conditions outlined above. Criteria in this 
Table 1.1 City/regional representation of case study firms

\begin{tabular}{ll}
\hline Team & City/Region \\
\hline Australia & Melbourne, Sydney, Brisbane, the Gold Coast \\
Canada & London, Ottawa, Calgary \\
England/United & Cambridgeshire, West Midlands, London, South East \\
Kingdom & England, South West England \\
United States & North Carolina (NC) - Research Triangle Region, Florida \\
& $($ FL $)$ - Tallahassee \\
\hline
\end{tabular}

regard included IT sub-sector, firm ownership arrangements and management structure, and the demographic composition of staff (for example, gender, age).

Such variation in the selection of firms into the sample creates a potential for bias, as some may have been specifically targeted or are particularly sensitive to certain workforce issues. This would be problematic if the aim of the study was to illustrate broad, generalizable trends; however, the intent here is to use mixed methodology to document experiences and processes relating to the nature of IT work.

\section{Case Study Selection}

The processes through which case studies were selected varied somewhat from country to country. In Canada, a sampling frame was defined using city and IT business directories. Then short, sampling frame telephone surveys were conducted in spring 2004 to gain access to firms and to learn more about the local IT landscape. Data were collected at this stage to inform regional IT context and case firm eligibility. Sampling frame respondents, usually firm owners or senior management personnel, were asked basic questions about the firm (for example, how long the firm had been in business, what products or services they provided, and so forth), its workforce (for example, number of employees, demographic composition) and the IT field in general (for example, subcontracting, skilled worker shortages). They were also asked if they would be willing to be contacted again about involvement in case studies and/or key informant interviews. Virtually all of the Canadian case firms were recruited through this sampling frame interview process; one case came from a contact list provided by one of four key informants.

For North Carolina, the US team employed a similar sampling frame methodology, drawing on regional professional association directories. Those who completed a sampling frame survey and whose firms were eligible (see criteria above) were asked if they would participate in a key 
informant interview; snowball sampling was used to recruit additional key informants. In-person, key informant interviews $(n=46)$ were conducted with industry representatives and business executives in order to learn about their perspectives on IT employment and workforce aging issues. These interviews also aided in the identification of firms that might be suitable for, and amenable to, participation in case studies. Because there were many fewer IT firms in the Tallahassee region, in Florida the US team directly recruited from a regional listing of IT firms.

The Australian team took a different approach to recruitment, forgoing the sampling frame interview method. Instead, the team used print media releases to raise awareness about the study and also disseminated study information to local business councils and technology networks. A formal business information kit was created for distribution through these various channels and interested parties returned an enclosed 'expression of interest' form to the team, which initiated the case study process. Many Australian case firms were therefore self-selected into the project; additional firms were tapped through referrals and social contacts.

For their research in England, the UK-based team employed media releases and an information kit. They also enlisted the help of the UK employer organization for the IT sector, which circulated details of the study to its members. One firm was recruited in this way; the rest were approached directly, cold-calling using contact information from technical directories, listings and recommendations.

Negotiations with potential case study firms began in mid-2004 and field work continued through early 2006. In most cases, negotiations entailed a series of telephone conversations and eventually a meeting between the research team leader and the company executive - usually the firm owner(s) and/or senior management. Owners and managers who agreed to have their company participate in the study signed a case study agreement form on behalf of the firm, outlining mutually determined parameters of participation. Typically, firms agreed to supply employee contact information, access to HR policies and employee participation time. In return, the research teams pledged to provide the participating company with first access to international research reports. Feedback reports were also provided to each firm in Canada and the US, and also to the larger British firms.

\section{Data Collection}

Whenever researchers entered a firm, they took observational notes about the environment and how work is structured. These notes were recorded after most company visits, including negotiations and interviews. Archival data were also collected for each case study company from publicly 
available sources such as business trade journals, magazine or newspaper articles and company websites, as well as firm-specific newsletters, human resource policy documents, annual reports and collective agreements. Where applicable (not all firms had such information available), HR documents and policy related material were provided by the CEO or administrative/HR staff. Finally, we conducted both in-depth, qualitative interviews and self-administered web surveys with managers and employees at each case study firm.

In-depth interviews were conducted with company executives, human resource managers, and employees in various occupational groups. Respondents were asked about their personal histories and experiences with IT work, and for management, their views about the IT field in general. As well, demographic attributes (for example, gender, age, job title, tenure at firm, family status) were gathered from the interviews for each participant. The number of interviews targeted at each firm depended largely on characteristics of the organization, such as number of employees and occupational groups. For many of the firms, and particularly the smaller ones, all employees and managers were invited to take part. In some cases, however, research teams solicited a particular profile of respondents using characteristics such as age, gender, occupational role or length of tenure; in other cases, management made autonomous exclusions - such as those in certain roles (for example, non-IT positions) or contract workers.

The firm provided contact information for potential participants, usually most or all of their employees, and qualitative interview invitations were delivered to each person. Employees were then contacted by telephone or email to see if they might be interested in participating. If an individual declined the request, there was no further attempt to involve that person. For those who agreed, a convenient time was arranged for an interview. Most interviews took place in a private office or meeting room at the respondent's place of work; occasionally, they occurred off work premises or via telephone at the discretion or preference of the interviewee. In some cases, a company liaison facilitated the scheduling. Interviews were recorded on tape and/or digitally. They generally lasted for about one hour, but ranged from 30 minutes to upwards of three hours.

Managers and employees were invited to complete a self-administered web survey. This solicited information about demographic characteristics, work history, attitudes about older and younger workers, non-standard employment practices, and so on. Retrospective questions about life course transitions, using well-established procedures that map out the timing and sequencing of individual lives, were also included. Web surveys took approximately 40 to 60 minutes to complete and could be filled out at the discretion of respondents from any location with internet access. An 
Table 1.2 Interview participation, survey response, and partial completion rates

\begin{tabular}{|c|c|c|c|c|c|c|}
\hline \multirow[t]{2}{*}{ Region } & \multicolumn{2}{|c|}{ Interviews } & \multicolumn{4}{|c|}{ Surveys } \\
\hline & \# & $\begin{array}{l}\text { participation } \\
\text { rate }(\%)^{\mathrm{a}}\end{array}$ & \# & $\begin{array}{l}\text { response } \\
\text { rate }(\%)^{\mathrm{a}}\end{array}$ & \# complete & $\begin{array}{c}\text { partials } \\
(\%)^{\mathrm{b}}\end{array}$ \\
\hline Australia & 91 & 82 & 81 & 22 & 69 & 15 \\
\hline Canada & 141 & 81 & 107 & 60 & 94 & 12 \\
\hline England & 61 & 100 & 125 & 75 & 117 & 6 \\
\hline $\begin{array}{l}\text { United } \\
\text { States }\end{array}$ & 106 & 90 & 139 & $50^{c}$ & 123 & 12 \\
\hline Total & 399 & 86 & 452 & 46 & 403 & 11 \\
\hline
\end{tabular}

Notes:

a. Participation and response rates are calculated using the number of interview transcripts/survey records out of the number of eligible respondents at each firm; eligible respondents are those who were invited to participate in the study

b. 'Partials' refers to the proportion of incomplete survey records (i.e., those who completed at least the first section, but did not complete the entire survey; does not include question non-responses)

c. One US case, a medium firm of $100+$ staff, experienced complications with data collection as company officials had not fully bought into study participation and as such, the project never really took off in that location. Removing these cases from the US response rate yields a cleaned response rate of $67 \%$. Responses from this company remain available for analysis.

important feature of the survey was the ability for respondents to complete it in stages, over days or weeks as required. The qualitative and quantitative components of this research are complementary, with the former providing information on meaning and process and the latter providing data that allows us to describe, contextualize and, to a limited extent, make generalizations about the nature of work in IT firms.

Management input and logistical considerations meant that not all employees in all firms were targeted for inclusion, particularly in larger companies. Across the 47 case study firms in four countries, there were 399 in-depth interviews and 452 web surveys (49 of those were partial completions). There was significant, but not perfect, overlap between the interviews and web surveys: 45 percent of respondents did both; 23 percent completed an interview but no survey; and 32 percent filled out a web survey only. This variation reflects both participant and researcherinitiated selection processes. Table 1.2 shows how the interviews and surveys are divided among the four countries.

The overall participation rate for the interviews is 86 percent, ranging from 81 percent in Canada to 100 percent in England. This figure represents 
the number of viable interview transcripts (i.e., electronic failures are excluded) out of the total number of eligible participants in each country. As noted previously, both researcher considerations and management dictates meant that not all employees at all firms were invited to participate. The participation rate reflects both direct and soft refusals from potential interviewees, as well as those who may have agreed but did not participate for whatever reason. The British team engaged in negotiations with managers and requested interviews once they were on site, which likely served to augment their participation rate.

The overall survey response rate is 46 percent and ranges from a low of 22 percent in Australia to 75 percent in England. These rates are influenced by lower participation in larger firms, where nearly all employees received a survey invitation, yet had little or no contact with the research team. In smaller firms, most or all employees were interviewed. Most respondents ( $n=403$, or 89 percent) completed the survey in full; regional partial completion rates were between 6 and 15 percent.

\section{Sample Characteristics - Firms}

From mid-2004 through early 2006, 47 firms took part in the study, with 586 unique individuals participating in interviews and/or web surveys, responding to questions on a wide range of topics. Table 1.3 presents characteristics of firms broken down by country. Keeping with the project's interest in understudied small and mid-sized businesses, the majority of case study firms ( $n=37$, or 79 percent) are quite small, employing just 4 to 20 people. Seven firms employed between 21 and 99 workers and three had between 100 and 250 staff.

Pinpointing how long these firms had been in business proved challenging because many had experienced an assortment of mergers, divisions, and name changes. Thus, the reported year of inception may vary on these terms. From the data on offer, firms were in operation on average 9.8 years; however, nearly half were less than 8 years old. Three-quarters of the firms were involved with software and/or web development. Six percent of the firms focused on systems analysis and support functions and 19 percent were involved in consulting, business or other endeavors.

\section{Sample Characteristics - Participants}

Table 1.4 contains a sample profile by country of select demographic characteristics of those who participated in the interviews (I) and web surveys (S).

Survey and interview samples overlap considerably so rather than 
Table 1.3 Firm characteristics

\begin{tabular}{|c|c|c|c|c|c|c|}
\hline & \multicolumn{4}{|c|}{ Region } & \multicolumn{2}{|c|}{ Total } \\
\hline & Australia & Canada & England & US & $n$ & $\%$ \\
\hline \multicolumn{7}{|l|}{ Firm size } \\
\hline $4-20$ & 9 & 17 & 4 & 7 & 37 & 79 \\
\hline $21-99$ & 1 & 1 & 2 & 3 & 7 & 15 \\
\hline $100-250$ & 1 & 0 & 1 & 1 & 3 & 6 \\
\hline \multicolumn{7}{|l|}{ Firm age } \\
\hline$>5$ years & 2 & 4 & 3 & 2 & 11 & 24 \\
\hline $5-10$ years & 5 & 6 & 2 & 6 & 19 & 40 \\
\hline $11-20$ years & 2 & 7 & 1 & 3 & 13 & 28 \\
\hline $21+$ years & 2 & 1 & 1 & 0 & 4 & 8 \\
\hline \multicolumn{7}{|l|}{ Firm specialization } \\
\hline $\begin{array}{l}\text { Software/web } \\
\text { development }\end{array}$ & 6 & 13 & 7 & 9 & 35 & 75 \\
\hline $\begin{array}{l}\text { Systems analysis/ } \\
\text { support }\end{array}$ & 1 & 1 & 0 & 1 & 3 & 6 \\
\hline Consulting/business & 4 & 4 & 0 & 0 & 8 & 17 \\
\hline other & 0 & 0 & 0 & 1 & 1 & 2 \\
\hline \# Case study firms & 11 & 18 & 7 & 11 & 47 & \\
\hline
\end{tabular}

discussing both, for illustrative purposes, the interview data will be discussed here. While we make no claim that the sample is representative of the IT industry as a whole, the profile is comparable to reports of industry and labor force composition (Duerden Comeau, 2004). In particular, our sample reflects industry trends in the distribution of gender (maledominated) and age (generally younger than overall labor force averages).

Interview participants ranged in age from 19 to 63, with a mean of 38.4 years. In England and the US, respondents were, on average, slightly older (40 years) compared to Canada and Australia (approximately 37.4 years). Nearly three-quarters (71 percent) of the sample are men. A small proportion of respondents (12.6 percent) were identified as visible minorities. There were considerable regional differences in this designation, with Australia and the US having higher proportions of visible minorities in their samples, compared to Canada and England.

In addition to demographic characteristics, occupational data were collected in the surveys and through descriptive information contained in the in-depth interviews. From the surveys, 80 percent of respondents report working in one of $26 \mathrm{IT} /$ technical roles, while 20 percent held non-IT 


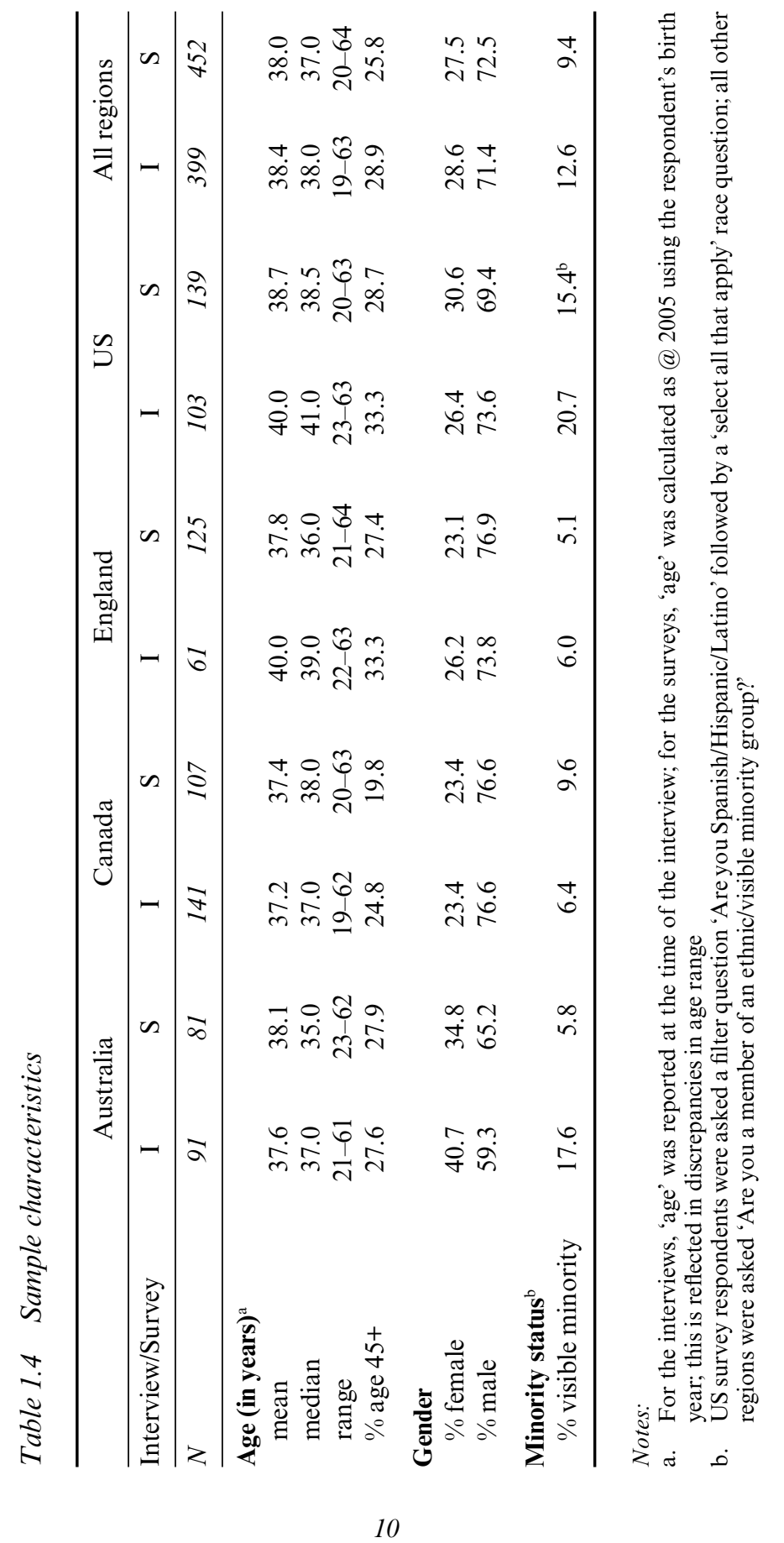


Table 1.5 Interview sample characteristics-occupations

\begin{tabular}{|c|c|c|c|c|c|c|}
\hline & Australia & Canada & England & US & all regions & $n$ \\
\hline Occupation & & & & & & 398 \\
\hline $\begin{array}{l}\text { IT/technical } \\
\text { role } \%\end{array}$ & 48.4 & 41.8 & 37.7 & 36.2 & 41.2 & 164 \\
\hline IT/other role \% & 14.3 & 14.2 & 14.8 & 34.3 & 19.6 & 78 \\
\hline $\begin{array}{l}\text { IT } / \text { management } \\
\text { role } \%\end{array}$ & 19.8 & 17.7 & 23.0 & 17.1 & 18.1 & 75 \\
\hline Non-IT role & 9.9 & 13.5 & 13.1 & 6.7 & 10.8 & 43 \\
\hline CEOs/Presidents & 7.7 & 12.8 & 11.5 & 5.7 & 9.5 & 38 \\
\hline$\%$ contractor & 7.8 & 12.1 & 0 & 0 & 6.3 & 398 \\
\hline $\begin{array}{l}\text { Job tenure (in } \\
\text { years) }\end{array}$ & & & & & & 388 \\
\hline mean & 5.2 & 5.3 & 7.5 & 3.3 & 5.1 & \\
\hline median & 3.0 & 4.0 & 7.0 & 2.0 & 4.0 & \\
\hline range & $0-29$ & $0-21$ & $0-30$ & $0-19$ & $0-30$ & \\
\hline$n$ & 91 & 141 & 61 & 103 & 399 & 399 \\
\hline
\end{tabular}

positions. Interview respondents were asked about their job and tasks and ten broad occupational categories were distilled from this more detailed qualitative data. These job groupings were further refined into IT/technical roles (programmers, engineers, technicians), IT/other roles (analysts, other), non-IT roles (administration, HR, sales/marketing), management (IT managers) and CEOs/presidents. By and large, most respondents (79 percent) work in positions that entail a considerable technical component programmers, engineers, technicians, analysts and IT management. Table 1.5 contains a sample profile by country of occupation-related characteristics of the workers who were interviewed. Australia and Canada included some contract workers in their samples, while England and the US did not. In some cases, based on the nature of their employment relationship, these workers would have been excluded from the original contact list by firm management. Finally, for job tenure, respondents were employed with their firms for a mean of 5.1 years. There was some regional variation, with British employees more likely, on average, to have longer tenures (7.5 years) and American workers shorter ones (3.3 years).

\section{Analysis}

The vastness and richness of the WANE data are at once a curse and a blessing. A curse because it is very difficult to make full use of all of the 
different data sources across all the different countries and a blessing because the possibility of doing so is there. In this book, our use of the data is modest. Some chapters rely only on quantitative data, others only on the qualitative data, and still others combine both the qualitative and the quantitative data in the analysis. All chapters use data from at least two countries and some use data from all of our study countries. Some of the chapters use case study analyses; others rely on individual level data analysis. In each of the chapters, authors outline their specific use of the data and the methods of analyses they use. Although some may quibble with the eclectic nature of our approach, this book, and a second, that is being published (McMullin, forthcoming) represent some of our preliminary steps in understanding the data and our aim is that they will shed some theoretical insights into the nature of work in the IT sector.

\section{THE LIFE COURSE PERSPECTIVE}

All of the chapters in this book draw on the life course perspective at least to some extent. The significance of the life course perspective is that it guides research in terms of problem identification and formulation and that it has 'made time, context, and process more salient dimensions of theory and analysis' (Elder, 1995: 104). The concept of 'social structure' is linked to the notion of 'context' in the above quotation and refers to the idea that social life is organized and patterned so that individuals, quite often unconsciously, act in a certain way because 'that's the way it has always been done.' Social structures influence all aspects of behavior because they represent 'taken-for-granted mental assumptions or modes of procedure that actors normally apply without being aware that they are applying them' (Sewell, 1992: 22). With respect to the life course, researchers in the European tradition consider how nation states and labor systems organize the life course and argue that the life course itself is a social structure because patterns in the sequencing and timing of life course transitions (for example, school-to-work; work-to-retirement) can be identified in societies (Marshall and Mueller, 2003). Alternatively, life course researchers in the North American tradition focus more on age structure and the associated roles and status positions that are organized on the basis of age (Marshall and Mueller, 2003). From our perspective these views of social structure are interconnected. Hence, in this book we consider how age and the life course structure working in the New Economy and how institutions such as labor systems and nation states, influence the structure of individuals' lives.

Social structures influence individuals' choices and behavior but they do 
not fully determine them (McMullin and Marshall, 1999). Hence, when we consider context and process as we do in life course research we must also consider human agency. Human agency plays a role in 'how individuals construct their own life courses through the choices and actions they take within the opportunities and constraints of history and social circumstances' (Marshall and Mueller, 2003: 20). Furthermore, individuals actively attempt to manage their lives - they make decisions about the timing of their careers and their training and they negotiate and navigate the social structures that serve to constrain their choices (Marshall and Mueller, 2003).

'Social time' is a fundamental consideration in life course research and is examined in multiple ways. First, individuals begin the dynamic and contextual aging process at birth. Age is thus a relative concept and what is 'old' or 'older' in one context may not be in another. Second, the historical time in which individuals are born influences individuals' experiences and the aging process. As a result, the particular economic and social context into which one is born, goes to school, and begins paid work, shapes life experiences. Third, individuals make transitions from one life course stage to another (e.g. from education to paid work) and, in most societies, the timing and sequencing of these transitions is patterned. At the same time, aging processes and the patterning of life course transitions are shaped by social contexts and cultural meanings that lead to some diversity in the sequencing of life course events and social transitions (Elder and O'Rand, 1995; Hagestad, 1990; Heinz, 2001; Marshall and Mueller, 2003; Mayer, 1988). Hence, with its emphasis on time, context, and aging processes, the life course framework allows us to examine how individuals negotiate paid work within the New Economy. In particular, there are two principles of the life course paradigm related to time - 'lives in time and place' and 'the timing and sequencing of lives' (Elder 1994, 1995) - that are considered in most of the chapters in this book and require further discussion here.

The life course perspective provides a conceptual framework for analyzing the complex relationships between individual lives and social change (Elder, 1994; Marshall and Mueller, 2003; Heinz, 2001). It allows us to examine how individuals manage social change and how their past experiences affect their ability to cope with such change. Structural characteristics of work in the New Economy and their potential influence on individual lives are important contextual considerations that relate to the life course concept, lives in time and place. Studies of the progression of individuals through life course stages and life events, must always take into account the context of economic and social change (Leisering and Leibfried, 1999; Heinz, 1997). Related to the New Economy, the idea here is that individual experiences will be different depending on the life stage one is at when changes to the economic order ensue (McMullin et 
al., 2007). In other words, life course research begins with the characteristics of a particular event (for example changes associated with the New Economy) and then assesses how this event affects individual lives while taking into account the age of individuals at the time of the historical event that led to social change.

We know that we are facing a new era of work which is increasingly characterized by greater individualism, job insecurity, risk, and instability (Smith, 2001). Traditional economies are giving way to ones marked by the commodification of knowledge and technological change (Castells, 1996). Governments and employers are increasingly stressing the need for workers to manage their own careers and encourage them to engage in lifelong learning to keep up with changes in technology. Do these changes in the structure and organization of work influence career development? Do they influence the wage negotiations? Are there unique pressures associated with working in a New Economy firm? How do workers keep up with new technology? These are among the questions related to the lives in time and place principle that are addressed in this book.

Thus far this discussion has focused much more on the lives in time part of the lives in time and place concept. Yet, 'place' is a central element of the analyses that are presented in this book. All the chapters in this book examine, in one way or another, the extent to which changes in the organization of IT work vary across our study countries. On the one hand, because education, labor, and social welfare policies vary significantly across our study countries we might expect differences in this regard. Alternatively, the global nature of the IT industry or the fact that labor market policies may apply more readily to large firms than to small ones, may mitigate some of these expected variations.

In old industrial economies, and at a time when life expectancies were lower, the timing and sequencing of lives was thought to be standardized through school-to-work-to-retirement transitions with few job disruptions or changes. Of course, there was a lot of irregularity in life course sequencing with significant variations along class, gender, and ethnic and racial lines (Connidis, 2009; Marshall and Mueller, 2003; Ranson, 1998; Rindfuss et al., 1987). For all groups, however, organizational restructuring in new economies may lead to shifts in patterns of career transitions (Heinz, 1997) and in patterns of training and knowledge acquisition. With this in mind, this book considers the following questions: To what extent does the structure of work in new economies lead to variation in the timing and sequencing of lives? Do workers transition in and out of careers with time off to retrain? To what extent does formal versus informal training matter in these transitions? Do family transitions influence career and training transitions?

The importance of family transitions points to the notion of linked 
lives,' the final life course concept that is considered in several chapters in this book. Discontinuous work histories and non-standard employment are characteristics of new economies but, historically, they are issues that have been confronted by many women who take primary responsibility for family caring even when employed (Duxbury and Higgins, 1994; Fast and Da Pont, 1997; Ginn et al., 2001). The life course concept of linked lives underscores the fact that an individual's actions in the labor market are intricately influenced by that individual's connections to others, including family members. Hence, a life course view of the New Economy must also be applied to the trajectory of family transitions in order to examine their mutual influence (Connidis, 2009; Szinovacz et al., 1992). A multifaceted life course perspective that incorporates the timing, duration, and sequencing of education, training, work, family, and retirement (Elder, 1994; Heinz, 2001) captures the complexities of balancing work and family over an increasingly individuated life course (Henretta, 2000). It also enhances multilevel analysis in which the experiences of individuals are linked to their relationships in various social domains (for example work and family) and with broader social, economic, and political issues. Recognizing the importance of linked lives in the context of New Economy work, our book considers the following questions: Does the structure and organization of work in New Economy firms influence the timing and sequencing of life course transitions among employees and do life course transitions outside paid work influence careers? Does it make sense to think about employment policy from a life course perspective that takes into account linked lives?

\section{CHAPTER OVER VIEWS}

This book is organized in three parts. Chapters 2 to 5 consider the concept of career and how the structure of work influences career development among IT workers. Chapters 6 and 7 consider issues of training, education and credentials within the context of IT employment and Chapters 8 to 10 consider the implications of the structure of IT work for employees' health and issues related to public policy.

\section{Making Careers in Changing Structures}

There is an emerging distinction between work and employment in the New Economy.

Work refers to the actual activities workers perform, the skills, information, and knowledge required to perform those activities and the social interaction 
involved in the process of performing that work. Employment, on the other hand, refers to the contractual relationship between employer and employee, including compensation systems and management practices. (Benner, 2002: 4)

Another emerging distinction is between jobs and careers, an issue that Victor W. Marshall, Jennifer Craft Morgan, and Sara B. Haviland take up in Chapter 2. In this chapter, the authors consider the differences between tasks, jobs and careers and argue that the way careers are experienced by IT workers is rather unique. Taking into account both the structural features of work in the IT sector as well as issues related to human agency and subjective careers, Marshall and his colleagues ask 'what constitutes a career in IT?' They show that IT careers are characterized by a lack of stability and career progression and that the structural organization of work in IT firms leads to much individuation of career ownership. This stands in contrast to 'old economy' industries in which internal labor markets had much more influence on an individuals' career structures.

In Chapter 3, Haviland, Craft Morgan, and Marshall further discuss the complexity of a New Economy careers by considering individuals' perceptions of career success. If the barometer of success in traditionally organized firms was perceived as working one's way up the career ladder in an internal labor market, how do employees gauge their success in the New Economy and what management practices are related to individuals' perceptions of career rewards? To address this question, Haviland and her colleagues construct a career rewards scale and distinguish the IT companies that fall in the top quintile on this scale, 'high career reward firms,' from those who fall in the bottom quintile, 'low career reward firms.' In high career reward firms, employees felt that they gained career rewards by being included in business decisions, firm-based training and development, and being able to maintain a balance between work and life. Management practices in these firms focused on inclusion and on developing both the firm and human capital among its employees. These rewards were absent in low career reward firms largely because the management practices in these firms favored client concerns over providing an enriching work environment for employees.

Gillian Ranson, in Chapter 4, takes the analysis of New Economy careers still further through a discussion of the 'boundaryless career' and an analysis of the career trajectories of IT workers in small firms. Focusing on men's careers (recognizing that men comprise the majority of IT workers), Ranson asks: (1) 'What place do small firms, founded at different time periods and with different histories, have in the career trajectories of men working in IT? and, (2) What theoretical model of "career" best fits the career trajectories of the men in the study?' In response to the 
first question, Ranson convincingly shows that small, viable IT firms play a role in launching, stabilizing, building, and sometimes saving, careers within the industry. Ranson takes the lives in time and place specifically into account by distinguishing between firms established before 2000 and those established after 2000. She shows that there are some opportunities in the older, more well-established firms to build long-term, singleemployer careers, adding further complexity to debates around the idea of boundaryless, New Economy careers.

The concept of risk in relation to New Economy careers is touched on in Chapters 2 through 4. Indeed, for many workers who are coming of age in the era of the New Economy, careers will be characterized by greater risk. The risks of doing business that were typically assumed by entrepreneurs and owners are increasingly being dispersed to workers (McMullin, et al., 2008). It seems then that a new category of employees has emerged, who like the entrepreneur of post-Fordist economic orders, must assume responsibility for risk without the possibility of deriving profit from the risk. This leads to matters related to the wage and how employees negotiate wages in an environment of instability and risk. Elizabeth Brooke examines these issues in Chapter 5 as she asks: 'What sets of distribution practices are in place?' and 'What are the implications for older workers and for women?' Brooke differentiates between two types of firms that are differentiated according to profitability and volatility. High-end, profitable firms linked remuneration strategies to productivity and a rational rewards system thereby removing individual agency from the wage negotiation process. These firms engaged in a 'chargeable hours' process which 'rationed time and money.' Wages were unstandardized and highly individualized in these firms and there was a focus on rewards and the ability to jump ahead of regular wage structures as a result. In theory, employees in more volatile firms could exercise their agency in the negotiation of the wage. Yet, in practice, the fragility of the firms left little room for owners to offer more. These firms were often limited in their capacity to make their payroll which heightened the risk for employees within these firms. Notably, older workers and women were more often employed in volatile firms and thus had fewer opportunities to achieve higher wages.

\section{Knowledge and Training}

In new economies, maintaining lifelong employment in one firm is increasingly rare (although possible as noted in Chapter 4) and there is a heightened emphasis on lifelong learning that enables workers to keep pace with technological change (Lowe, 2001). But how is lifelong learning achieved 
in New Economy employment? Do employees transition in and out of formal educational programs as they negotiate their employment in the New Economy and are certain workers better able to do this than others? What role do informal training mechanisms play in keeping workers' skills current? Do training patterns vary depending on age, gender or job status? Chapters 6 and 7 address these questions.

In Chapter 6, Tracey L. Adams and Erin I. Demaiter consider selflearning and skill acquisition drawing on Manuel Castell's idea of the 'self-programmable' worker - 'workers who are flexible, adaptable and quick to retrain.' They further examine the roles that formal education, credentials and self-learning play in developing 'self-programmable' employees. This chapter provides descriptive data on the types of skill acquisition process in which IT workers engage, and the various transitions that IT workers make from school or training programs to paid work. It also considers IT workers' perceptions of skill acquisition and its importance, and an examination of whether factors such as age or gender are influential in either regard. Although one might expect little variation in the extent to which IT workers engage in independent learning, Adams and Demaiter find some variation on that score especially with respect to credential attainment. In short, Adams and Demaiter conclude that today's flexible, self-programmable worker is also a credentialed worker, but not necessarily a credentialed worker in the traditional sense.

Neil Charness and Mark C. Fox consider the issue of training in relation to age, job status, and gender in Chapter 7. Although age did not influence the likelihood of receiving training in the past year, compared to younger workers, older workers engaged in fewer training days and among those who reported no training, older workers had lower levels of self-efficacy than younger workers. Men were more likely than women to view training as unnecessary, managers were more likely than non-managers to use the skills gained from formal training, and non-IT workers (sales and administrative staff) were less likely to report that training was available than IT workers within these firms. Finally, there was an overall perception that there was a lack of time for adequate training. And, as Chapter 8 shows, the lack of time for training is linked to stress.

\section{Stress Outcomes - Policy Solutions}

Chapters 8 to 10 consider the implications of working and aging in the New Economy for stress outcomes and policy matters. The stress associated with aging and working in the New Economy is taken up in Chapter 8. In this chapter, Kim M. Shuey and Heather Spiegel show how negotiating the need to keep skills current within the structural context of IT 
work is stressful for workers and is experienced differently by workers depending on their age and life course stage. Stress and burnout are often normalized among IT workers in firms that organize work around tight deadlines and long working hours and create workplace cultures that glorify 16-hour work days. Shuey and Spiegel show that life course transitions, particularly the transition to parenthood, heighten the workrelated stress and burnout that workers experience (see also Connidis and Kemp, forthcoming) and that relationships with friends and family members are often strained because of the pressures associated with work. Employees and employers actively engage in strategies that help to reduce stress levels. Employers would sometimes attempt to create fun work atmospheres, encourage employees to take time off, or put in place flexible work hour options in an effort to alleviate employee stress. For their part, some employees would actively set boundaries between their work and personal lives in an effort to manage stress. But, often, escapist strategies that involve daydreams of lives outside of IT or in management positions served as a way for workers to manage their stress.

As the chapters in this book show, the pressures associated with aging and working in the New Economy are not insignificant. As we noted earlier, a critical issue facing industrialized countries is the retention and retraining of workers throughout the life course. The question that we face then is how policies can be transformed to consider the changing needs and capacities of workers across the life course so that they can remain productive over a longer term. Considering 'flexicurity' and transitional labor market (TLM) policy ideas from Europe that explicitly considered life course issues in their development, in Chapter 9, Martin Cooke and Kerry Platman examine how employees currently navigate insecure employment, and how policies might be formulated to better provide security.' Cooke and Platman show how labor market transitions are influenced by other life course transitions often having to do with family formation and development. They argue that life course informed policies such as flexicurity and TLM hold promise for enabling workers to better negotiation employment insecurity in the New Economy.

In our final chapter we conclude by considering the research contained in this book and how it has contributed to our understanding of working in the New Economy. We consider how employment relations and the structure of paid work in the New Economy may be unique and we show how the life course perspective enables us to shed light on the simultaneous processes of aging and working. Aging has generally been ignored in studies of paid work but, as the chapters in this book show, working and aging are interrelated, dynamic processes that influence career development and employees' well-being. 


\section{NOTES}

1. Excerpts from this section are taken from E. Jovic, J.A. McMullin and T. Dureden Comeau (forthcoming). Chapter 2, Methods. In J.A. McMullin (ed.), Gender, Age and Work in the New Economy: The Case of Information Technology Firms. Kelowna: University of British Columbia Press.

2. Our focus is on one industry within IT or ICT services, namely the computer design and related services Industry. In Industry Canada data, Total ICT services typically includes the following: software publishers, telecommunications services, cable and other program distributors, internet service providers, data processing, hosting and related Services, and often, ICT wholesaling. Where possible in this report we utilize the term IT reflecting our interest in the computer design sector (NAICS 54151) of ICT services.

\section{REFERENCES}

Benner, C. (2002), Work in the New Economy: Flexible Labor Markets in Silicon Valley, Malden, MA: Blackwell Publishing.

Bjornsson, K. (2001), 'Computer services: strong employment growth and low labour productivity despite high labour costs and a highly-educated labour force', Statistics in Focus: Industry, Trade and Services, theme 4-11/2001, catalogue no. KS-NP-01-011-EN-I, Eurostat: European Communities.

Brooke, L., L. Rolland, E. Jones and C. Topple (2004), Australian Country Report, WANE International Report No. 3, London, ON: University of Western Ontario, Workforce Aging in the New Economy (WANE), available at www.wane.ca.

Castells, M. (1996), The Rise of the Network Society, Malden, MA: Blackwell Publishers.

Connidis, I.A. (2009), Family Ties, 2nd edn, Thousand Oaks, CA: Sage.

Connidis, I.A., and C. Kemp (forthcoming), 'Negotiating work and family in the information technology industry', in J.A. McMullin (ed.), Working in Information Technology Firms: Intersections of Gender and Aging, Kelowna, BC: University of British Columbia Press.

Da Pont, M. (2003), 'Building the perfect system: an analysis of the computer systems design and related services industry', in Analytical Paper Series-Service Industries Division, Statistics Canada, (catalogue no. 63F0002XIE-No. 45, Ottawa: Statistics Canada.

Duerden Comeau, T. (2004), Cross-national Comparison of Information Technology Employment, WANE International Report No. 5, London, ON: The University of Western Ontario, Workforce Aging in the New Economy (WANE), available at www.wane.ca.

Duxbury, L. and C. Higgins (1994), 'Families in the economy', in M. Baker (ed.), Canada's Changing Families: Challenges to Public Policy, Ottawa: Vanier Institute of the Family, pp. 29-40.

Elder, G.H., Jr. (1994), 'Time, human agency, and social change: perspectives on the life course', Social Psychology Quarterly, 51 (1), 4-15.

Elder, G.H., Jr. (1995), 'The life course paradigm: historical, comparative, and developmental perspectives', in P. Moen, G.H. Elder, Jr. and K. Luscher (eds), Examining Lives and Context: Perspectives on the Ecology of Human Development, Washington, DC: American Psychological Association Press, pp. 101-39. 
Elder, G.H., Jr. and A. O'Rand (1995), 'Adult lives in a changing society', in K. Cook, G. Fine and J.S. House (eds), Sociological Perspectives on Social Psychology, New York: Allyn and Bacon, pp. 452-75.

Fast, J. and M. Da Pont (1997), 'Changes in women's work continuity', Canadian Social Trends, Catalogue no. 11-008- XPE, pp. 2-7, Ottawa: Statistics Canada.

Ginn, J., D. Street and S. Arber (2001), 'Cross-national trends in women's work', in J. Ginn, D. Street and S. Arber (eds), Women, Work and Pensions: International Issues and Prospects, Philadelphia, PA: Open University Press, pp. 11-30.

Hagestad, G. (1990), 'Social perspectives on the life course', in R.H. Binstock and L.K. George (eds), Handbook of Aging and the Social Sciences, 2nd edn, New York: Van Nostrand-Reinhold, pp. 36-61.

Heinz, W.R. (1997), 'Status passages, social risks, and the life course: a conceptual framework', in W.R. Heinz (ed.), Theoretical Advances in Life-course Research. Vol. I of Status Passages and the Life Course, 2nd edn, Weinheim, Germany: Deutscher Studien Verlag, pp. 9-21.

Heinz, W.R. (2001), 'Work and the life course: a cosmopolitan-local perspective', in V.W. Marshall, W.R. Heinz, H. Krüger and A. Verma (eds), Restructuring Work and the Life Course, Toronto, ON: University of Toronto Press, pp. 3-28.

Henretta, J.C. (2000), 'The future of age integration in employment', The Gerontologist, 40 (3), 286-92.

Jovic, E., J.A. McMullin and T. Dureden Comeau, (forthcoming), 'Appendix A: methods', in J.A. McMullin (ed.), Working in Information Technology Firms: Intersections of Gender and Aging, Kelowna, BC: University of British Columbia Press.

Leisering, L. and S. Leibfried (1999), Time and Poverty in Western Welfare States, Cambridge: Cambridge University Press.

Lowe, G.S. (2001), 'Youth, transitions, and the new world of work', in V.W. Marshall, W.R. Heinz, H. Krüger, and A. Verma (eds), Restructuring Work and the Life Course, Toronto, ON: University of Toronto Press, pp. 29-44.

Marshall, V.W. (1999), 'Reasoning with case studies: issues of an aging workforce', Journal of Aging Studies, 13 (4), 377-89.

Marshall, V.W. and M.M. Mueller (2003), 'Theoretical roots of the life-course perspective', in W.R. Heinz and V.W. Marshall (eds), Social Dynamics of the Life Course: Transitions, Institutions, and Interrelations, New York: Aldine De Gruyter, pp. 3-32.

Mayer, K.U. (1988), 'German survivors of World War II: the impact on the life course of the collective experience of birth cohorts', in M.W. Riley (ed.), in association with B.J. Huber and B.B. Hess, Social Structures and Human Lives: Vol. 1. Social Change and the Life Course, Newbury Park, CA: Sage, pp. 229-46.

McMullin, J.A. (ed.) (forthcoming), Gender, Age and Work in the New Economy: The Case of Information Technology Firms, Kelowna, BC: University of British Columbia Press.

McMullin, J.A. and V.W. Marshall (1999), 'Structure and agency in the retirement process: a case study of Montreal garment workers', in C. Ryff and V.W. Marshall (eds), The Self and Society in Aging Processes, New York: Springer, pp. 305-38.

McMullin, J.A., T. Duerden Comeau and E. Jovic (2007), 'Generational affinities and discourses of difference: a case study of highly skilled information technology workers', British Journal of Sociology Volume, 58 (2), 297-316. 
McMullin, J.A., V.W. Marshall, T. Duerden Comeau and C. Gordon (2008), 'Aging and employment relations: dilemmas of owners and workers in a risk society', paper presented at the American Sociological Association Meetings, Boston, MA: August.

Ragin, C.C. (2000), Fuzzy-set Social Science, Chicago, IL and London: University of Chicago Press.

Ranson, G. (1998), 'Education, work and family decision-making: finding the "right time" to have a baby', Canadian Review of Sociology and Anthropology, 35 (4), 483-99.

Ranson, G. (2003), Understanding the 'New Economy': A Conceptual Journey, WANE Working Paper No. 3, London, ON: University of Western Ontario, Workforce Aging in the New Economy (WANE), available at www.wane.ca.

Rindfuss, R.R., C.G. Swicegood and R.A. Rosenfeld (1987), 'Disorder in the life course: how common and does it matter?', American Sociological Review, 52 (6), 785-801.

Sewell, W.H.J., Jr. (1992), 'A theory of structure: duality, agency, and transformation', American Journal of Sociology, 98, 1-29.

Smith, V. (2001), Crossing the Great Divide: Worker Risk and Opportunity in the New Economy, Ithaca, NY: ILR Press.

Szinovacz, M., D. Ekerdt and B.H. Vinick (1992), 'Families and retirement: conceptual and methodological issues', in M. Szinovacz, D.J. Ekerdt and B.H. Vinick (eds), Families and Retirement, Newbury Park, CA: Sage, pp. 1-19.

United States Census Bureau (2006), '2006 county business patterns', accessed 23 March 2009 at www2.census.gov/csd/susb/2006/usalli06.xls. 